Article

\title{
Insights into the Anaerobic Hydrolysis Process for Extracting Embedded EPS and Metals from Activated Sludge
}

\author{
Barbara Tonanzi ${ }^{1,2}$, Agata Gallipoli ${ }^{1, *}$, Andrea Gianico ${ }^{1}$, Maria Cristina Annesini ${ }^{2}$ and Camilla Maria Braguglia ${ }^{1}$ \\ 1 Water Research Institute, National Research Council of Italy, IRSA-CNR, Area della Ricerca RM1, \\ Via Salaria km 29.300, 00015 Monterotondo Roma, Italy; barbara.tonanzi@irsa.cnr.it (B.T.); \\ andrea.gianico@irsa.cnr.it (A.G.); camilla.braguglia@irsa.cnr.it (C.M.B.) \\ 2 Dipartimento di Ingegneria Chimica, Università degli Studi di Roma "La Sapienza", 00184 Rome, Italy; \\ mariacristina.annesini@uniroma1.it \\ * Correspondence: agata.gallipoli@irsa.cnr.it
}

Citation: Tonanzi, B.; Gallipoli, A.; Gianico, A.; Annesini, M.C.; Braguglia, C.M. Insights into the Anaerobic Hydrolysis Process for Extracting Embedded EPS and Metals from Activated Sludge. Microorganisms 2021, 9, 2523. https://doi.org/10.3390/ microorganisms 9122523

Academic Editor: Hermann J. Heipieper

Received: 30 October 2021 Accepted: 03 December 2021 Published: 6 December 2021

Publisher's Note: MDPI stays neutral with regard to jurisdictional claims in published maps and institutional affiliations.

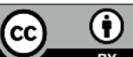

Copyright: $@ 2021$ by the authors. Licensee MDPI, Basel, Switzerland. This article is an open access article distributed under the terms and conditions of the Creative Commons Attribution (CC BY) license (https://creativecommons.org/licenses/by/4.0/).

\begin{abstract}
The amount of sewage sludge generated from wastewater treatment plants globally is unavoidably increasing. In recent years, significant attention has been paid to the biorefinery concept based on the conversion of waste streams to high-value products, material, and energy by microorganisms. However, one of the most significant challenges in the field is the possibility of controlling the microorganisms' pathways in the anaerobic environment. This study investigated two different anaerobic fermentation tests carried out with real waste activated sludge at high organic loading rate $\left(10 \mathrm{~g} \mathrm{COD} \mathrm{L}^{-1} \mathrm{~d}^{-1}\right)$ and short hydraulic retention time (HRT) to comprehensively understand whether this configuration enhances extracellular polymeric substance (EPS) and metal solubilisation. The quantity of EPS recovered increased over time, while the chemical oxygen demand to EPS ratio remained in the range 1.31-1.45. Slightly acidic conditions and sludge floc disintegration promoted EPS matrix disruption and release, combined with the solubilisation of organically bound toxic metals, such as $\mathrm{As}, \mathrm{Be}, \mathrm{Cu}, \mathrm{Ni}, \mathrm{V}$, and $\mathrm{Zn}$, thereby increasing the overall metal removal efficiency due to the action of hydrolytic microorganisms. Bacteroidetes, Firmicutes, and Chloroflexi were the most abundant phyla observed, indicating that the short HRT imposed on the systems favoured the hydrolytic and acidogenic activity of these taxa.
\end{abstract}

Keywords: anaerobic hydrolysis; extracellular polymeric substances; waste activated sludge; toxic metals; high throughput 16S rRNA gene sequencing; microbial communities

\section{Introduction}

Wastewater treatment plants (WWTPs) are typically considered as facilities in which contaminated water is treated to produce a clean effluent and an inevitable semi-solid byproduct (sewage sludge). However, in recent years their high potential in terms of resource recovery has gained increasing attention. One of the key components for maximising resource recovery in a WWTP is the sludge produced through the primary and secondary treatment steps. After primary physical-chemical treatments, the biodegradable organic matter contained in the wastewater is removed by the secondary activated sludge process. At this stage, wastewater is treated by active biomass constituted by biological aggregates named flocs. The active biomass assimilates the organic matter, thus reducing the oxygen demand, and producing an excess biomass known as waste activated sludge (WAS). The virtuous shift to a more efficient resource recovery facility should integrate biochemical, physical, and biological conversion processes to extract value, if any, from complex waste streams as activated sludge. Flocembedded microorganisms produce soluble microbial products and extracellular polymeric substances (EPS) due to biological or mechanical stress [1]. Soluble microbial products consist of cellular components released into solution during cell lysis, diffused 
across the cell membrane, or excreted for other purposes [2]. Furthermore, EPS typically remain within the sludge flocs. EPS are mixtures of macromolecular substances such as polysaccharides, proteins, humic and fulvic acids, lipids, and nucleic acids, which have been found to occur in the intracellular space of microbial aggregates [3,4], due to active secretion, shedding of cell surface material, cell lysis, and adsorption from the environment [2,5]. These biopolymers support several important cellular functions, such as binding of metal ions or organic compounds, water retention, and microbial adhesion to a surface [5].

Due to the nature of their association with cells and flocs, and considering the extraction techniques used to separate them, EPS can be broadly classified as soluble ("slime" polymers) and bound fractions. The bound EPS are closely attached to microbial cells or flocs, whereas the soluble EPS are able to move freely among sludge flocs being dissolved in the surrounding liquor [6,7]. These soluble EPSs are therefore identical to soluble microbial products (SMP), which are soluble cellular components that are released and dissolved into solution [2]. Both fractions are generally separated by centrifugation: the supernatant contains the soluble EPS whereas the bound EPS remain attached to the solid particles.

The EPSs in activated sludge, forming a three-dimensional matrix of aggregates as biofilms or flocs, account for $10-40 \%$ of the sludge dry weight. Moreover, $75-89 \%$ of the extracellular organic carbon can be attributed to proteins and saccharides. Extracellular carbohydrates, proteins, and nucleic acids all have binding capacities to form the complexes with heavy metals [8]. In addition, Comte et al. [9] suggested that soluble EPS had a more significant adsorptive capability for heavy metals with respect to bound EPS. EPS have received increasing attention for a number of wastewater treatment applications, such as particle flocculation, heavy metal adsorption, toxic organic chemical removal, and dye decolourisation [10]. Therefore, the extraction of EPS from sludge presents several application perspectives, including industrial ones.

Anaerobic digestion (AD) starts by breaking down the sludge structure through hydrolysis, increasing the sludge surface area and the soluble organics content [11]. Novak et al. [12] showed that the amount of proteins and carbohydrates released in the disintegration of anaerobic sludge is strongly dependent on the hydraulic retention time (HRT) in a range between 1 and 9 days. At the same time, HRT can also affect the transformation of EPS into short chain fatty acids, which have commercial applications even if they are not in their pure forms [13]. Therefore, the release of embedded EPS from biosolids through appropriate pre-treatments and/or biological hydrolysis can be very effective [14].

The anaerobic hydrolysis stage of biogenic residues poses a promising platform for the wide-spread development of biorefinery systems. More studies and investments are needed to reduce initial costs and encourage their implementation at an industrial scale for a sustainable bio-economy $[15,16]$.

For these reasons, the objectives of this study were focused on understanding the sludge anaerobic degradation mechanisms of the hydrolysis step carried out at constant high organic loading rate (OLR) and short HRT ( 3 and 4 days), by investigating the release of EPS and metals, the fate of proteins and polysaccharides, and the process performances in terms of methane production and organics removal. To further understand the underlying mechanisms in such systems, the microbial community was investigated.

\section{Materials and Methods}

\subsection{Digester Operation}

Two distinct anaerobic reactors were run with the aim to study the waste activated sludge (WAS) hydrolysis. The reactors, completely mixed with a working volume of $3 \mathrm{~L}$, were operated at mesophilic temperature $\left(37^{\circ} \mathrm{C}\right)$ in semi-continuous mode, feeding sludge from Monday to Friday. Both reactors, seeded with anaerobic inoculum deriving 
from a full-scale digester treating sewage sludge (TS $=30.2 \pm 2 \mathrm{~g} \mathrm{~L}^{-1}$; VS $=15 \pm 3 \mathrm{~g} \mathrm{~L}^{-1}$; $\left.\mathrm{COD}_{\text {tot }}=26.3 \pm 5 \mathrm{~g} \mathrm{~L}^{-1}\right)$, were fed with real WAS, dynamic thickened ( $2000 \mathrm{~g}$ for $3 \mathrm{~min}$ ) and conveniently diluted to maintain an OLR of $10 \pm 3 \mathrm{~g} \mathrm{COD} \mathrm{L}^{-1} \mathrm{~d}^{-1}$. Reactor I was operated at hydraulic retention time (HRT) of 4 days; Reactor II at HRT of 3 days. Table 1 shows the characteristics of the feedstocks used for R-I and R-II. Due to the duration of the tests and to different sampling periods, WAS characteristics were partly affected by seasonal effects; the sludge used as feed for R-II presented higher VS content (\%TS) and lower soluble COD with respect to the one fed to R-I.

Table 1. Average characteristics of the feedstocks used for R-I and R-II.

\begin{tabular}{|c|c|c|}
\hline & Feed R-I & Feed R-II \\
\hline $\mathrm{TS}\left(\mathrm{g} \mathrm{L}^{-1}\right)$ & $43.6 \pm 1$ & $33.4 \pm 7.1$ \\
\hline $\mathrm{VS}\left(\mathrm{g} \mathrm{L}^{-1}\right)$ & $27.1 \pm 1.1$ & $23.6 \pm 4.5$ \\
\hline VS/TS (\%) & $62 \pm 1$ & $71 \pm 3$ \\
\hline $\operatorname{COD}_{t}\left(\mathrm{~g} \mathrm{~L}^{-1}\right)$ & $44.7 \pm 5$ & $38 \pm 8$ \\
\hline $\mathrm{COD}_{1.2 \mu \mathrm{m}}\left(\mathrm{mg} \mathrm{L}^{-1}\right)$ & $325 \pm 31$ & $205 \pm 68$ \\
\hline $\mathrm{sCOD}\left(\mathrm{mg} \mathrm{L}^{-1}\right)$ & $275 \pm 28$ & $80 \pm 25$ \\
\hline Sol Proteins (mg COD L-1) & $203 \pm 15$ & $78 \pm 18$ \\
\hline Sol Carbohydrates (mg COD L-1) & $24 \pm 2$ & $8.5 \pm 5$ \\
\hline $\mathrm{N}-\mathrm{NH}_{4}\left(\mathrm{mg} \mathrm{L}^{-1}\right)$ & $90 \pm 10$ & $105 \pm 10$ \\
\hline$P$ tot $\left(\mathrm{g} \mathrm{kg}^{-1} \mathrm{TS}\right)$ & $18.6 \pm 1.8$ & $15.8 \pm 1.5$ \\
\hline $\mathrm{N}$ tot $\left(\mathrm{g} \mathrm{kg}^{-1} \mathrm{TS}\right)$ & $50 \pm 3$ & $51 \pm 2$ \\
\hline $\mathrm{BMP}\left(\mathrm{mL} \mathrm{CH}_{4} \mathrm{~g}^{-1} \mathrm{VS}_{\mathrm{fed}}\right)$ & \multicolumn{2}{|c|}{$0.11 \pm 0.01$} \\
\hline
\end{tabular}

\subsection{Analytical Procedure}

APHA standard methods were used to determine total and volatile solids [17]. To analyse the soluble phase, the effluent was centrifuged (10 min at $5500 \mathrm{rpm})$ and the particulate sludge matter was removed. The resulting phase was filtrated through $0.45 \mu \mathrm{m}$ pore size membrane filters. Total and soluble chemical oxygen demand (COD) were analysed in duplicates by means of COD Cell Test by Spectroquant Merck (EPA method 410.4). Total nitrogen was determined photometrically according to Koroleff's method through cell tests by Spectroquant Merck. Ammonium nitrogen $\left(\mathrm{NH}_{4}{ }^{+}-\mathrm{N}\right)$ was determined according to APHA Standard Methods. For protein and carbohydrates determination, effluent aliquots were filtered through filters with $1.2 \mu \mathrm{m}$ pores (GF/C Whatman). Protein content was calculated by means of the modified Lowry Kit for Protein Determination (Sigma-Aldrich P 5656, St. Louis, MO, USA). Carbohydrate determination was based on a colorimetric modified Dubois method, reported in Pagliaccia et al. [18].

Protein and carbohydrate concentrations were converted to COD equivalent by multiplying by 1.5 and 1.07 , respectively [19].

\subsection{EPS Extraction}

A quantity of $500 \mathrm{~mL}$ effluent was centrifuged at $\mathrm{g}(\sim \mathrm{rpm})$ for $10 \mathrm{~min}$ at $4{ }^{\circ} \mathrm{C}$. The supernatant was collected as soluble-slime EPS (sEPS) and dialysed successively against demineralised water at least eight times to remove low-molecular weight metabolites [20].

The dialysed components were freeze-dried (Alpha 1-4 LDplus, Martin Christ, Osterode am Harz, Germany) to obtain dry solids. The dried sEPS were weighed to assess the concentration in the processed effluent.

EPS recovery was based on the influent COD using the equation:

$$
\begin{aligned}
\operatorname{EPS} \text { recovery }(\%) & =\frac{\left(C_{e p s} \times Q_{e f f l}\right)}{\left(\operatorname{COD}_{\text {inf }} \times Q_{\text {inf }}\right)} \\
Q_{e f f l} & =Q_{\text {inf }}
\end{aligned}
$$


where $Q_{i n f}$ and $Q_{\text {eff }}$ are the flow rates $\left(\mathrm{L} \mathrm{d}^{-1}\right)$ of the influent feed and of the effluent, respectively; $C_{e p s}$ is the soluble EPS concentration in the effluent $\left(\mathrm{g} \mathrm{Leffl}^{-1}\right)$; and $C O D_{\text {inf }}$ is the influent $\mathrm{COD}\left(\mathrm{g} \mathrm{L}^{-1}\right)$.

\subsection{DNA Extraction and Microbial Community Analysis}

Biomass was sampled from the reactors at the end of the operation and was immediately stored at $-20{ }^{\circ} \mathrm{C}$. One $\mathrm{mL}$ of digestate (corresponding to $\sim 0.25 \mathrm{~g}$ wet weight) was used to extract DNA with the PowerSoil DNA Isolation kit (MoBio, - Carlsbad, CA). DNA was eluted with $100 \mu \mathrm{L}$ sterile distilled water and the concentration and purity determined by a NanoDrop 2000 c spectrophotometer (Thermo Scientific, Waltham, MA, USA). The genomic DNA was stored at $-80^{\circ} \mathrm{C}$ for several days and then used for high throughput $16 \mathrm{~S}$ rRNA gene sequencing.

16S rRNA V1-3 and V3-5 variable regions were sequenced for bacterial and archaeal community analysis, respectively. High throughput $16 \mathrm{~S}$ rRNA gene sequencing used protocol were previously reported in Tonanzi et al. [21]. QIIME2 version 2018.2 was used to process, quality filter, and analyse the raw sequences. The demultiplexed reads were processed with the DADA2 pipeline to identify amplicon sequence variants (ASVs) [22]. Taxonomy was assigned using a pre-trained naïve-Bayes classifier based on the 16S rRNA database at a $99 \%$ similarity of SILVA132 release [23].

Total ASVs generated from each sample were used to perform the diversity analyses using the statistical software PAST 3 (version 2.17) [24]. Briefly, the Shannon index (H) measures diversity considering the number of ASVs and increases as diversity increases. Shannon diversity divided by the logarithm of the number of taxa provides the Equitability index (J). This index measures the evenness with which individuals are divided among the taxa present in the sample. Simpson's diversity index calculates a diversity score for a community. It is based on both the number of different species in the community and the number of individuals present for each of those species. Approximate confidence intervals for all indexes were computed with a bootstrap procedure (default 9999) and a 95\% confidence interval was then calculated.

\section{Results and Discussion}

\subsection{Performance of Fermentation Reactors}

Waste activated sludge, due to its biological origin, was rich in $\mathrm{N}$ and $\mathrm{P}$, and mainly composed of particulate organics. The VS/TS ratio, which provides an indication of the organic fraction in the sludge solids, was $0.6-0.7$ lower with respect to typical value ranging from 0.7 and 0.8 [25], suggesting low biodegradability due to the long sludge age of the plant ().

As expected, for the six heavy metals $(\mathrm{Cd}, \mathrm{Cu}, \mathrm{Hg}, \mathrm{Ni}, \mathrm{Pb}$, and $\mathrm{Zn}$ ) having limits set out in the EU Directive for sludge utilisation in agriculture, the concentrations in the WAS were very low, and also do not pose problems in the case of inevitable metal enrichment due to solids removal of stabilisation processes (Figure 1). Additional limit values provided for the European countries are, however, very different, and almost all countries provide limit values for total chromium and, in some cases, arsenic. Italy also recently introduced (law No. 130/2018) limits for beryllium and selenium [26]. 


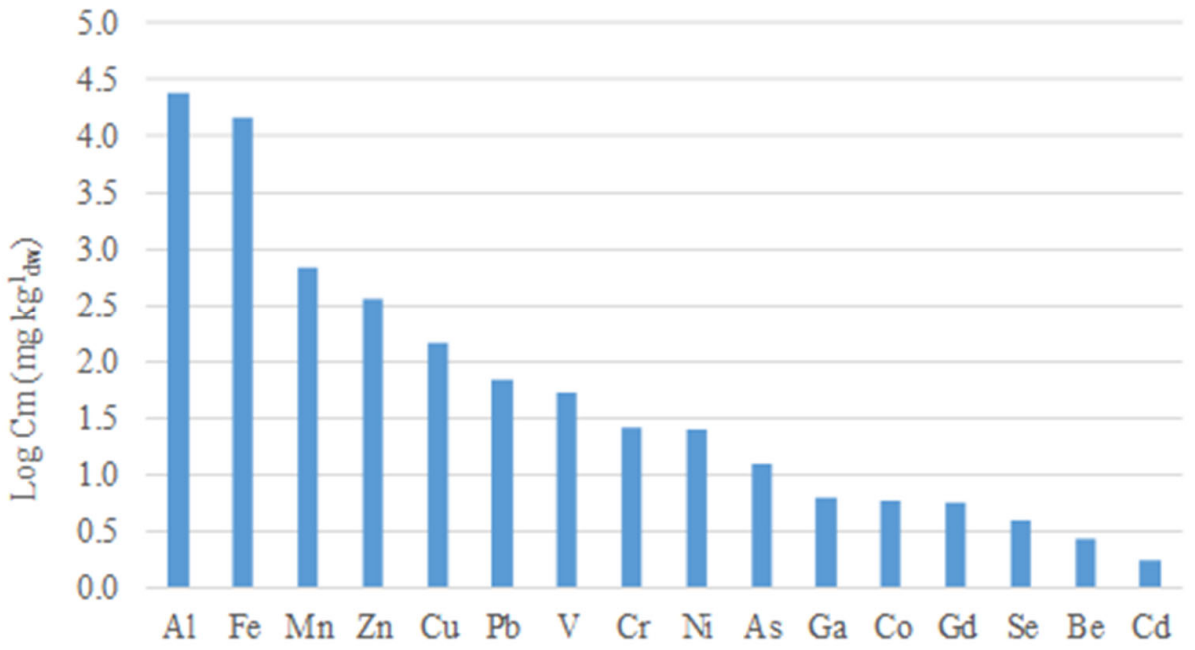

Figure 1. Average total concentrations $\left(\log \mathrm{Cm}, \mathrm{mg} \mathrm{kg}^{-1}\right)$ of heavy metals and metalloids in raw waste activated sludge used in this study.

Relevant concentration of As and Se, potentially toxic metalloids found in this WAS, could be ascribed to the input coming from natural background sources typical of the territory of Central Italy, which also affected the quality of the biosolids quality to be disposed of [27].

Fermentation-based anaerobic bioleaching process was carried out in order to investigate the efficiency of biological hydrolysis and acidification to extract these metals, together with the EPS, from sludge (see Section 3.2). Fermentation performance was evaluated at mesophilic temperature at an OLR of $10 \pm 1 \mathrm{~g} \mathrm{COD} \mathrm{L}^{-1} \mathrm{~d}^{-1}$ and HRT of 4 days (Reactor I) and 3 days (Reactor II). The OLR applied was approximately four times higher than that of a typical anaerobic digester. The $\mathrm{pH}$ value of $\mathrm{R}-\mathrm{I}$ showed a slightly decreasing trend over the week (because of daily feeding that promoted acidification of the system) but recovered to neutrality during the weekend (Figure 2). On the contrary, by decreasing the HRT to $3 \mathrm{~d}$ (Reactor II), the $\mathrm{pH}$ continuously decreased to 6.5 during the first 3 weeks of operation (approximately 5 HRT), before remaining stable and slightly acidic until the end of the test (Figure 2).

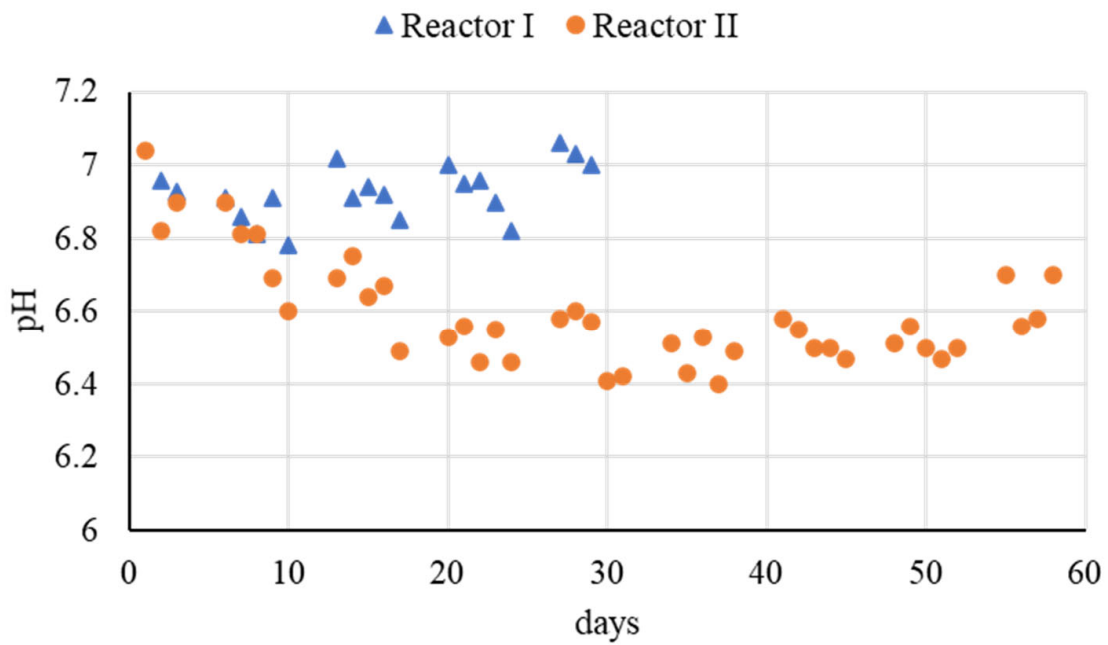

Figure 2. Comparison of $\mathrm{pH}$ value between R-I and R-II during the entire operation. 
An accumulation of propionate and acetate was observed in Reactor II, with an acidification degree of $23 \pm 2 \%$. Conversely, in Reactor I the acidification degree was lower (only $9 \%$ ) due to the removal of VFAs during the process. The accumulation of acetic and propionic acids in Reactor II could be attributed to the instability of the methanogenic process due to the low HRT applied.

The performances in terms of methane production and solids reduction confirmed this trend: the specific methane production of Reactor I was significantly higher, namely 0.07 against the $0.045 \mathrm{LCH}_{4} \mathrm{~g}^{-1} \mathrm{VS}_{\text {fed }}$ of Reactor II, with a VS removal of $25 \%$ (against $10 \%$ of Reactor II). These low methane yields confirmed the impact of short HRTs on methanogens [28].

\subsection{Solubilisation of Organics and Metals from Sludge Disintegration}

Table 2 summarises the main substances detected in the reactor effluents during the fermentation process. It can be seen that after the start-up period the effluents contained higher proteins, polysaccharides, phosphorus, $\mathrm{NH}_{4}{ }^{+}$, and VFAs than the raw WAS supernatant (see Table 2) due to sludge disintegration and hydrolysis processes occurring in anaerobic fermentation. These variations were in agreement with other authors' observations [29-31].

Table 2. Characteristics of effluent produced in Reactor I and Reactor II, in two different sampling times.

\begin{tabular}{|c|c|c|c|c|}
\hline \multirow[b]{2}{*}{ Effluent } & \multicolumn{2}{|c|}{ Reactor I } & \multicolumn{2}{|c|}{ Reactor II } \\
\hline & Day 17 & Day 30 & Day 24 & Day 52 \\
\hline $\mathrm{COD}_{1.2 \mu \mathrm{m}}\left(\mathrm{mg} \mathrm{L}^{-1}\right)$ & 1450 & 1100 & 410 & 598 \\
\hline Sol Proteins (mg COD L-1) & 756 & 1040 & 270 & 336 \\
\hline Sol Carbohydrates (mg COD L-1) & 55 & 86 & 33 & 39 \\
\hline Soluble COD $\left(\mathrm{mg} \mathrm{L}^{-1}\right)$ & 1300 & 650 & 250 & 410 \\
\hline VFA (mg COD L-1) & 550 & 52 & 10 & 95 \\
\hline S-EPS $\left(\mathrm{mg} \mathrm{L}^{-1}\right)$ & 75 & 220 & 38 & 110 \\
\hline Yield (mg sEPS g-1 CODfed) & 1.5 & 4.7 & 1.1 & 2.7 \\
\hline Soluble P $\left(\mathrm{mg} \mathrm{L}^{-1}\right)$ & 120 & 137 & 88 & 130 \\
\hline Total COD $\left(\mathrm{g} \mathrm{L}^{-1}\right)$ & $29 \pm 1.5$ & $30 \pm 2$ & $29.5 \pm 1.5$ & $27.5 \pm 1.5$ \\
\hline
\end{tabular}

The increase in carbohydrate and protein contents in both reactors indicated that the degradation rates of these compounds were lower than their release rates from sludge flocs, in particular for the protein fraction. Nevertheless, a significant portion of the soluble COD in R-I was removed between days 17 and 30 due to VFA's transformation into methane, which increased significantly.

Specific hydrolysis rates, calculated for each reactor on the basis of COD balances and VS concentrations, were $0.063 \pm 0.01$ and $0.052 \pm 0.01 \mathrm{~g} \mathrm{COD} \mathrm{g}^{-1} \mathrm{VSd}^{-1}$, respectively. These values were comparable to the one reported by Guo et al. [32], who operated a CSTR at higher HRT (12d) and lower OLR $\left(4.4 \mathrm{~g} \mathrm{COD} \mathrm{L}^{-1} \mathrm{~d}^{-1}\right)$. The low values obtained in this study can be attributed to the high stabilisation degree of the WAS used.

Soluble-slime EPS were extracted from the effluents after 17 and 30 days for R-I, and 24 and 52 days for R-II, in order to follow the sEPS production dynamics (Table 2). The amount recovered in each extraction increased over time, while the COD to EPS ratio remained in the range of 1.31-1.45. Slight acidic conditions and sludge floc disintegration promoted soluble-slime EPS release into the supernatant during the operation. On the contrary, Guo et al. [32] experienced a stable and low level of the slime fraction of EPS during batch anaerobic digestion of WAS, due to its possible conversion into methane.

The sEPS in Reactor I at the end of the test (characterised by a SCOD value of $310 \pm$ $25 \mathrm{mg} \mathrm{L}^{-1}$, half of the total sCOD in the reactor) was composed of $55 \%$ proteins and $40 \%$ 
carbohydrates, with a recovery of $4.7 \pm 0.8 \mathrm{mg} \mathrm{g}^{-1} \mathrm{COD}_{\text {fed. }}$ In Reactor II, where the acidogenesis was more effective and stable, the sEPS was lower, namely $2.7 \pm 0.5 \mathrm{mg} \mathrm{g}^{-1} \mathrm{COD}_{\mathrm{fed}}$, probably due to their transformation into VFAs. The high protein-to-carbohydrate ratio in the sEPS, which can likely be ascribed to the high sludge age of the activated sludge process [33], can provide high binding capacity to metals due to the larger molecular size of proteins with respect to polysaccharides [34].

In this study, the soluble concentration of $\mathrm{As}, \mathrm{Be}, \mathrm{Cu}, \mathrm{Ni}, \mathrm{V}$, and $\mathrm{Zn}$ in the reactors during the tests was significantly correlated $(p<0.05)$ with the sEPS concentration extracted from the effluents, and the association was very strong (Pearson correlation coefficient between 0.80 and 0.93 ). Arsenic, with good mobility, tended to migrate to the supernatant [35] and can be easy to remove. It is interesting to note that in a previous study the authors found that the solubilisation of elements such as As, Ni, V, and Zn was strictly related to the degree of sludge disintegration with pre-treatments such as ultrasounds and thermal hydrolysis [27]. These metals, in fact, are progressively released into the soluble phase by increasing organic matter solubilisation and floc conformational change, confirming that the solubilisation of the EPS can lead to the release of adsorbed metals [36].

\subsection{Microbial Community Analysis}

Bacterial and archaeal 16S rRNA high throughput sequences analysis was performed on representative samples taken from both reactors at the end of the tests (Figures 3 and 4). Diversity estimators - including the Simpson index (1-D), Shannon index (H) and Equitability index $(J)$ - were used to investigate the diversity of the microbiome, and the main outputs are shown in Table 3.

a.

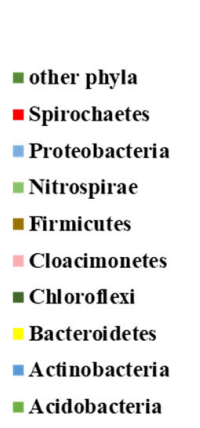

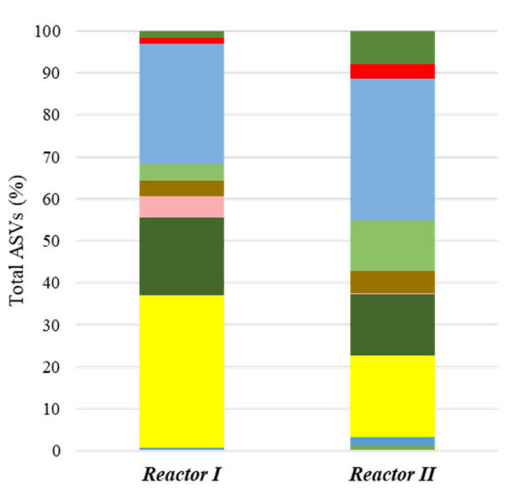

b.

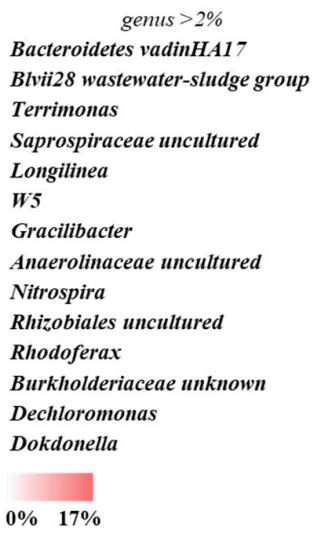

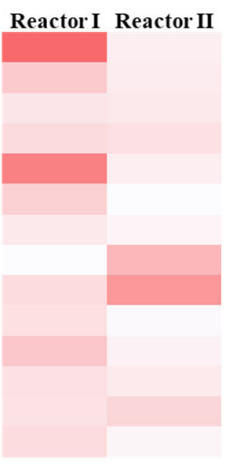

Figure 3. Bacterial microbiome estimated by high throughput $16 \mathrm{~S}$ rRNA gene sequencing in R-I and R-II sampled at the end of the operations at taxonomical phylum (a) and genera (b) levels. Only taxonomy groups having $\geq 2 \%$ of abundance in at least one sample are shown. 


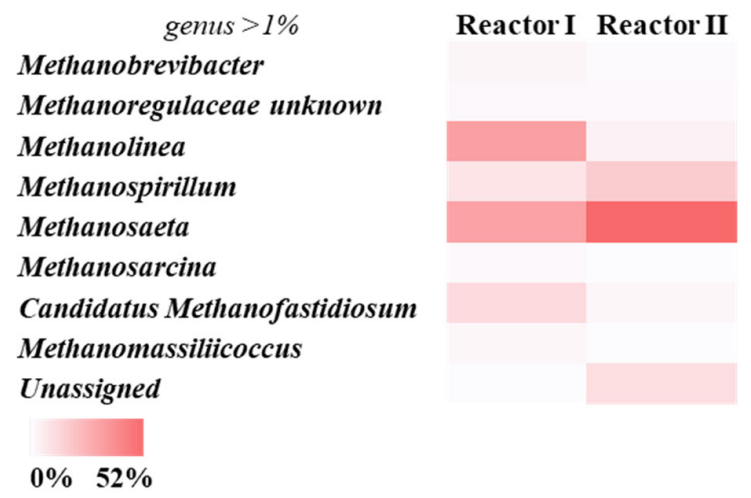

Figure 4. Frequency heat map of archaeal communities at taxonomical genera levels (only taxonomy groups having $\geq 1 \%$ of abundance in at least one sample are shown) observed in Reactor I and II. The colour intensity in each cell shows the relative ASV abundance.

Table 3. Statistics analysis of the microbial $16 \mathrm{~S}$ rRNA gene libraries obtained from the highthroughput $16 \mathrm{~S}$ rRNA gene sequencing.

\begin{tabular}{ccccc}
\hline \multirow{3}{*}{ Bacteria } & & Simpson_1-D & Shannon_H & Equitability_J \\
& R-I & 0.9274 & 3.17 & 0.7743 \\
\multirow{2}{*}{ Archaea } & R-II & 0.9735 & 4.56 & 0.8308 \\
& R-I & 0.7647 & 1.77 & 0.6535 \\
& R-II & 0.6807 & 1.66 & 0.5108 \\
\hline
\end{tabular}

The results showed that the bacterial biodiversity was higher in R-II than R-I, considering all the investigated indexes; by comparison, for the archaeal community, the higher biodiversity was obtained in R-I.

Bacterial analysis revealed that Bacteroidetes, Chloroflexi, Proteobacteria, and Firmicutes represented the core microbiome inhabiting both reactors (accounting for $73 \%$ and $87 \%$ of the total ASVs, for R-I and R-II, respectively, Figure 3a).

Bacteroidetes and Proteobacteria were the major phyla retrieved in both reactors $(36 \%$ and $29 \%$ in R-I and 19\% and 34\% in R-II, respectively, Figure 3a) and have previously been described as key microorganisms for hydrolysis and VFA production from various substrates under anaerobic conditions [28]. The Bacteroidetes phylum was found in systems where hydrolysis and acidification of the substrate occurred [37]. Moreover, Bacteroidetes can potentially release more proteinaceous EPS - which aided its establishment in the reactor $[38,39]$ - so their abundance in R-I can be correlated with the high amount of protein released into the effluent of this system (Table 2). These taxa included Bacteroidetes vadinHA17 and Rikenellaceae families (which contains Blvii28 wastewater-sludge group; Figure $3 b)$. The latter groups were composed of hydrolytic anaerobic bacteria [40], and their presence, in particular in R-I, can also be associated with the higher hydrolysis rate observed for this reactor $\left(0.063 \pm 0.01 \mathrm{~g} \mathrm{COD} \mathrm{g}^{-1} \mathrm{VS} \mathrm{d}^{-1}\right)$.

Conversely, the abundance of ASVs associated with the Proteobacteria phylum, in particular in R-II, was principally affiliated to aerobic or facultative anaerobic microorganisms (such as Rhodoferax, Dechloromonas, and Dokdonella genera, Figure 3b) that were reported as predominant microorganisms in activated sludge [41,42]. It is well known that the presence of these microorganisms in anaerobic reactors - in addition to members of the Nitrospira phylum (up to $12 \%$ in R-II) - can be due to the short HRT imposed on the systems. In fact, their appearance as major populations in these processes is likely due to incomplete digestion, unlike other populations, such as methanogens, syntrophs, and fermenters [42]. 
The Chloroflexi phylum represented the third most abundant anaerobic group found in the investigated systems (about $18 \%$ and $15 \%$ of the total ASVs in R-I and R-II, respectively. Figure 3a), followed by Firmicutes ( $4 \%$ and $5 \%$ of the total ASVs, Figure 3a). Chloroflexi and Firmicutes play a clear role in hydrolysis and acidogenesis, and their relevant presence may be due to short HRTs imposed [32]. In particular, Chloroflexi-reported to be responsible for carbohydrate degradation in anaerobic digesters [43] - was more abundant in Reactor I in which a more intense degradation occurred. The Longilinea genus represented about $15 \%$ of the total sequences affiliated to this phylum in R-I (Figure 3b). This genus is characterised by strictly anaerobic filamentous microorganisms and studies demonstrated that its growth is enhanced in co-cultivation with hydrogenotrophic methanogens [44]; therefore, its abundance can be attributed to the presence of this type of metabolism (Figure 4).

Members of Firmicutes phylum have been identified to hydrolyse and ferment large numbers of organic compounds under different anaerobic conditions $[45,46]$. In fact, they were more abundant in Reactor II, in which the production of VFAs was higher (acidification degree of $23 \pm 2 \%$, Figure $3 a$ ).

The relative abundance of Cloacimonetes (about $5 \%$ of the total ASVs) in Reactor I (only $0.07 \%$ of the sequences affiliated to this phylum was observed in R-II) suggests the possible presence of a syntrophic oxidation of the propionate pathway in this system [47]. This evidence could therefore explain the low acidification degree in R-I (only 9\%): the presence of these microorganisms may prevent the accumulation of VFA (in particular propionate) due to the synergistic work with the hydrogenotrophic methanogens also present in the system.

Regarding the archaeal profile, almost all the found sequences were affiliated with the phylum Euryarchaeota for both reactors (about $95 \%$ and $80 \%$ of the total ASVs, respectively. Figure 4). As previously mentioned, genus level microbial community analysis revealed that acetoclastic and hydrogenotrophic metabolism coexisted in R-I. In fact, Methanosaeta were observed for $32 \%$ of the total ASVs, whereas Methanolinea, Methanospirillum, and Candidatus Methanofastidiosum-microorganisms associated with the production of methane from hydrogen - were present for 33\%, 9\%, and 12\% of the total ASVs, respectively (Figure 4). By comparison, Methanosaeta, a well-known taxon capable of performing acetate degradation to produce $\mathrm{CH}_{4}$, was predominant in R-II, covering $52 \%$ of the total ASVs. Their significant presence in R-II was likely a result of increased concentration of acetic acid, indicating that acetoclastic methanogenesis was significant in this reactor [48].

The higher archaeal biodiversity (Table 3), together with higher methane yield of RI with respect to R-II, may be correlated with the possibility of producing methane from different substrates. Moreover, the structural shift from hydrogenotrophic to acetoclastic methanogens observed between R-I and R-II was probably due to the selective pressures imposed on the microbial population by the reduction in HRT in the second system investigated [32].

\section{Conclusions}

The results of this study shed light on the EPS release from a low-cost feedstock, such as waste activated sludge, during the anaerobic fermentation stage carried out at high OLR and short HRT. The organically bound toxic metals, such as As, $\mathrm{Be}, \mathrm{Cu}, \mathrm{Ni}, \mathrm{V}$, and $\mathrm{Zn}$, were released due to the disruption of the EPS matrix, thereby increasing the overall metal removal efficiency due to the action of hydrolytic microorganisms in a "cascade biorefinery" perspective. In fact, the properties of the EPS (biodegradable, rich in proteins and carbohydrates, easily extractable) make them attractive biopolymers that can be used as bioflocculants and cost-effective adsorbents, with a significant impact in transforming WWTPs into resource recovery facilities. However, there is still a need to identify the best operating conditions (HRT, OLR, type of waste activated sludge) to maximise the extraction of EPS and minimize the production of methane while maintaining the effectiveness of metal extraction. 
Author Contributions: Conceptualization, C.M.B. and M.C.A.; methodology, B.T. and A.G. (Agata Gallipoli); validation, B.T., A.G. (Agata Gallipoli) and A.G. (Andrea Gianico); formal analysis, B.T. and C.M.B.; investigation, B.T. and A.G. (Agata Gallipoli); resources, B.T., A.G. (Agata Gallipoli) and A.G. (Andrea Gianico); data curation, B.T. and C.M.B.; writing-original draft preparation, B.T. and C.M.B.; writing - review and editing, B.T., C.M.B. and M.C.A.; visualization, B.T. and C.M.B.; supervision, C.M.B., M.C.A. and A.G. (Andrea Gianico); project administration, C.M.B. All authors have read and agreed to the published version of the manuscript.

Funding: This work was funded by Fondazione Cariplo, via the REVENUE project "3-routes platform for REcovery of high Value products, ENergy and bio-fertilizer from Urban biowastE" contract \#2019-2407.

Institutional Review Board Statement: Not applicable.

Informed Consent Statement: Not applicable.

Data Availability Statement: Not applicable.

Acknowledgments: Sludge sampling was conducted with the kind assistance and cooperation of the Municipal Agency for Electricity and the Environment of Rome (ACEA S.p.a.). Authors wish to thank the University of Rome "La Sapienza", which funded and supported the doctoral work of Barbara Tonanzi, and Maria Cristina Gagliano and Emanuel Diniz (Wetsus Centre, The Netherlands) for EPS extraction support.

Conflicts of Interest: The authors declare no conflict of interest.

\section{References}

1. Rosenberger, S.; Laabs, C.; Lesjean, B.; Gnirss, R.; Amy, G.; Jekel, M.; Schrotter, J. Impact of Colloidal and Soluble Organic Material on Membrane Performance in Membrane Bioreactors for Municipal Wastewater Treatment. Water Res. 2006, 40, 710720. https://doi.org/10.1016/j.watres.2005.11.028.

2. Laspidou, C.S.; Rittmann, B.E. A Unified Theory for Extracellular Polymeric Substances, Soluble Microbial Products and Active and Inert Biomass. Water Res. 2002, 36, 2711-2720.

3. Harimawan, A.; Ting, Y. Investigation of Extracellular Polymeric Substances (EPS) Properties of P. Aeruginosa and B. Subtilis and Their Role in Bacterial Adhesion. Colloids Surf. B Biointerfaces 2016, $146,459-467$. https://doi.org/10.1016/j.colsurfb.2016.06.039.

4. Turu, C.I.; Turkcan-kayhan, C.; Kazan, A.; Yildiz-ozturk, E.; Akgol, S.; Yesil-Celiktas, O. Synthesis and Characterization of Cryogel Structures for Isolation of EPSs from Botryococcus Braunii. Carbohydr. Polym. 2016, 150, 378-384. https://doi.org/10.1016/j.carbpol.2016.05.027.

5. Flemming, H.; Wingender, J. The Biofilm Matrix. Nat. Rev. Microbiol. 2010, 8, 623-633. https://doi.org/10.1038/nrmicro2415.

6. Rosenberger, S.; Kraume, M. Filterability of Activated Sludge in Membrane Bioreactors. Desalination 2002, 146, $373-379$.

7. Sheng, G.; Yu, H.; Li, X. Extracellular Polymeric Substances (EPS) of Microbial Aggregates in Biological Wastewater Treatment Systems : A Review. Biotechnol. Adv. 2010, 28, 882-894. https://doi.org/10.1016/j.biotechadv.2010.08.001.

8. Zhang, D.; Wang, J.; Pan, X. Cadmium Sorption by EPSs Produced by Anaerobic Sludge under Sulfate-Reducing Conditions. J. Hazard. Mater. 2006, 138, 589-593. https://doi.org/10.1016/j.jhazmat.2006.05.092.

9. Comte, S.; Guibaud, G.; Baudu, M. Biosorption Properties of Extracellular Polymeric Substances (EPS) Resulting from Activated Sludge According to Their Type: Soluble or Bound. Process. Biochem. 2006, 41, 815-823. https://doi.org/10.1016/j.procbio.2005.10.014.

10. Ajao, V.; Bruning, H.; Rijnaarts, H.; Temmink, H. Natural Fl Occulants from Fresh and Saline Wastewater: Comparative Properties and Fl Occulation Performances. Chem. Eng. J. J. 2018, 349, 622-632. https://doi.org/10.1016/j.cej.2018.05.123.

11. Braguglia, C.M.; Gianico, A.; Mininni, G. Comparison between Ozone and Ultrasound Disintegration on Sludge Anaerobic Digestion. J. Environ. Manage. 2012, 95, S139-S143. https://doi.org/10.1016/j.jenvman.2010.07.030.

12. Novak, J.T.; Sadler, M.E.; Murthy, S.N. Mechanisms of Floc Destruction during Anaerobic and Aerobic Digestion and the Effect on Conditioning and Dewatering of Biosolids. Water Res. 2003, 37, 3136-3144. https://doi.org/10.1016/S0043-1354(03)00171-4.

13. Garcìa, M.; Oulego, P.; Dìaz, M.; Collado, S. Non-Energetic Chemical Products by Fermentation of Hydrolyzed Sewage Sludge. Sustainability 2021, 13, 5499.

14. Banu, J.R.; Devi, T.P.; Kannah, R.Y.; Kavitha, S.; Kim, S.; Muñoz, R.; Kumar, G. A Review on Energy and Cost Effective Phase Separated Pretreatment of Biosolids. Water Res. 2021, 198, 117169. https://doi.org/10.1016/j.watres.2021.117169.

15. Dahiya, S.; Kumar, A.N.; Sravan, J.S.; Chatterjee, S.; Sarkar, O.; Mohan, S.V. Food Waste Biore Fi Nery : Sustainable Strategy for Circular Bioeconomy. Bioresour. Technol. 2018, 248, 2-12. https://doi.org/10.1016/j.biortech.2017.07.176.

16. Battista, F.; Frison, N.; Bolzonella, D. Energy and Nutrients ' Recovery in Anaerobic Digestion of Agricultural Biomass : An Italian Perspective for Future Applications. Energies 2019, 12, 3287. 
17. APHA. Standard Methods for the Examination of Water and Wastewater; American Public Health Association, Washington DC, 1998; ISBN 9780875532356.

18. Pagliaccia, P.; Gallipoli, A.; Gianico, A.; Montecchio, D. Single Stage Anaerobic Bioconversion of Food Waste in Mono and CoDigestion with Olive Husks: Impact of Thermal Pretreatment on Hydrogen and Methane Production. Int. J. Hydrogen Energy 2016, 41, 905-915. https://doi.org/10.1016/j.ijhydene.2015.10.061.

19. Rittman, B.E.; McCarty, P.L. Environmental Biotechnology: Principles and Applications; McGraw-Hill Int.: London, UK, 2001.

20. Liu, H.; Fang, H.P. Extraction of Extracellular Polymeric Substances (EPS) of Sludges. J. Biotechnol. 2002, 95, $249-256$.

21. Tonanzi, B.; Braguglia, C.M.; Gallipoli, A.; Montecchio, D.; Pagliaccia, P.; Rossetti, S.; Gianico, A. Anaerobic Digestion of Mixed Urban Biowaste: The Microbial Community Shift towards Stability. N. Biotechnol. 2020, 55, $108-117$. https://doi.org/10.1016/j.nbt.2019.10.008.

22. Callahan, B.J.; Mcmurdie, P.J.; Rosen, M.J.; Han, A.W. HHS Public Access. Nat Methods 2016, 13, 581-583. https://doi.org/10.1038/nmeth.3869.DADA2.

23. Quast, C.; Pruesse, E.; Yilmaz, P.; Gerken, J.; Schweer, T.; Yarza, P.; Peplies, J.; Glöckner, F.O. The SILVA Ribosomal RNA Gene Database Project: Improved Data Processing and Web-Based Tools. Nucleic Acids Res. 2013, 41, 590-596. https://doi.org/10.1093/nar/gks1219.

24. Hammer, Ø.; Harper, D.A.; Ryan, P.D. Past: Paleontological Statistics Software Package for Education and Data Analysis. Palaeontol. Electron. 2001, 4, 5-7. https://doi.org/10.1016/j.bcp.2008.05.025.

25. von Sperling, M.; Goncalves, R.F. Sludge Treatment and Disposal-Sludge Characteristics and Production; IWA Publishing: London, UK, 2007; ISBN 9781843391661.

26. Gianico, A.; Braguglia, C.M.; Gallipoli, A.; Montecchio, D.; Mininni, G. Land Application of Biosolids in Europe : Possibilities , Con-Straints and Future Perspectives. Water 2021, 13, 103.

27. Tonanzi, B.; Gallipoli, A.; Cristina, M.; La, C.; Gianico, A.; Maria, C. Pre-Treatments and Anaerobic Hydrolysis as Strategical Key Steps for Resource Recovery from Sludge: The Role of Disintegration Degree in Metals Leaching. J. Environ. Chem. Eng. 2021, 9, 104649. https://doi.org/10.1016/j.jece.2020.104649.

28. Yesil, H.; Molaey, R.; Calli, B.; Evren, A. Removal and Recovery of Heavy Metals from Sewage Sludge via Three-Stage Integrated Process. Chemosphere 2021, 280, 130650. https://doi.org/10.1016/j.chemosphere.2021.130650.

29. Chen, Y.; Jiang, S.; Yuan, H.; Zhou, Q.; Gu, G. Hydrolysis and Acidification of Waste Activated Sludge at Different PHs. Water Res. 2007, 41, 683-689. https://doi.org/10.1016/j.watres.2006.07.030.

30. Li, X.; Yuan, Y.; Jin, R.; Huang, Y.; Ma, J. High Efficiency of Excess Sludge Reduction and Dewaterability Using Newly Prepared Alkaline Ferrate Pretreatment Combined with Anaerobic Digestion. J. Environ. Manage. 2019, 243, $350-357$. https://doi.org/10.1016/j.jenvman.2019.05.032.

31. Ruhyadi, R.; Chen, Y.; Shen, N.; Yan, W.; Liang, Z.; Wang, H. Multiple Uses of Magnesium Chloride during Waste Activated Sludge Alkaline Fermentation. Bioresour. Technol. 2019, 290, 121792. https://doi.org/10.1016/j.biortech.2019.121792.

32. Guo, H.; Oosterkamp, M.J.; Tonin, F.; Hendriks, A.; Nair, R.; Van Lier, J.B.; Kreuk, M. De Reconsidering Hydrolysis Kinetics for Anaerobic Digestion of Waste Activated Sludge Applying Cascade Reactors with Ultra-Short Residence Times. Water Res. 2021, 202, 117398. https://doi.org/10.1016/j.watres.2021.117398.

33. Sanin, F.D.; Clarkson, W.W.; Vesilind, P.A. Sludge Engineering: The Treatment and Disposal of Wastewater Sludges; DEStech Publications Inc.: Lancaster, PA, USA, 2011.

34. Pan, X.; Liu, J.; Zhang, D.; Chen, X.; Song, W.; Wu, F. Binding of Dicamba to Soluble and Bound Extracellular Polymeric Substances (EPS) from Aerobic Activated Sludge: A Fluorescence Quenching Study. J. Colloid Interface Sci. 2010, 345, $442-447$. https://doi.org/10.1016/j.jcis.2010.02.011.

35. Xu, X.; Wang, P.; Zhang, J.; Chen, C.; Wang, Z.; Kopittke, P.M.; Kretzschmar, R.; Zhao, F. Microbial Sulfate Reduction Decreases Arsenic Mobilization in Fl Ooded Paddy Soils with High Potential for Microbial Fe Reduction+. Environ. Pollut. 2019, 251, 952960. https://doi.org/10.1016/j.envpol.2019.05.086.

36. Dewil, R.; Baeyens, J.; Appels, L. Enhancing the Use of Waste Activated Sludge as Bio-Fuel through Selectively Reducing Its Heavy Metal Content. J. Hazard. Mater. 2007, 144, 703-707. https://doi.org/10.1016/j.jhazmat.2007.01.100.

37. Chen, Y.; Jiang, X.; Xiao, K.; Shen, N.; Zeng, R.J.; Zhou, Y. Enhanced Volatile Fatty Acids ( VFAs ) Production in a Thermophilic Fermenter with Stepwise PH Increase e Investigation on Dissolved Organic Matter Transformation and Microbial Community Shift. Water Res. 2017, 112, 261-268. https://doi.org/10.1016/j.watres.2017.01.067.

38. Gao, D.; Zhang, T.; Tang, C.Y.; Wu, W.; Wong, C.; Lee, Y.H.; Yeh, D.H.; Criddle, C.S. Membrane Fouling in an Anaerobic Membrane Bioreactor: Differences in Relative Abundance of Bacterial Species in the Membrane Foulant Layer and in Suspension. J. Memb. Sci. 2010, 364, 331-338. https://doi.org/10.1016/j.memsci.2010.08.031.

39. Yu, Z.; Wen, X.; Xu, M.; Huang, X. Characteristics of Extracellular Polymeric Substances and Bacterial Communities in an Anaerobic Membrane Bioreactor Coupled with Online Ultrasound Equipment. Bioresour. Technol. 2012, 117, $333-340$. https://doi.org/10.1016/j.biortech.2012.04.075.

40. Rosenberg, E.; DeLong, E.F.; Lory, S.; Stackebrandt, E.; Thompson, F. The Prokaryotes, Springer, Heidelberg, Germany, 2014; ISBN 9783642389535.

41. Zhang, T.; Shao, M.; Ye, L. 454 Pyrosequencing Reveals Bacterial Diversity of Activated Sludge from 14 Sewage Treatment Plants. ISME J. 2012, 6, 1137-1147. https://doi.org/10.1038/ismej.2011.188. 
42. Mei, R.; Nobu, M.K.; Narihiro, T.; Kuroda, K.; Wu, Z.; Ye, L.; Lee, P.K.H.; Lee, P.; Mu, J.; Van Lier, J.B.; et al. Operation-Driven Heterogeneity and Overlooked Feed-Associated Populations in Global Anaerobic Digester Microbiome. Water Res. 2017, 124, 77-84. https://doi.org/10.1016/j.watres.2017.07.050.

43. Zhao, X.; Sun, Y.; Huang, J.; Wang, H.; Tang, D. Effects of Soil Heavy Metal Pollution on Microbial Activities and Community Diversity in Different Land Use Types in Mining Areas. Environ. Sci. Pollut. Res. 2020, 2, 20215-20226.

44. Yamada, T.; Imachi, H.; Ohashi, A.; Harada, H.; Hanada, S.; Kamagata, Y.; Sekiguchi, Y. Longilinea Arvoryzae Gen . Nov ., Sp . Nov ., Strictly Anaerobic, Filamentous Bacteria of the Phylum Chloroflexi Isolated from Methanogenic Propionate-Degrading Consortia. Int. J. Syst. Evol. Microbiol. 2007, 57, 2299-2306. https://doi.org/10.1099/ijs.0.65098-0.

45. Karthikeyan, O.P.; Selvam, A.; Wong, J.W.C. Hydrolysis-Acidogenesis of Food Waste in Solid-Liquid-Separating Continuous Stirred Tank Reactor (SLS-CSTR) for Volatile Organic Acid Production. Bioresour. Technol. 2016, 200, $366-373$. https://doi.org/10.1016/j.biortech.2015.10.017.

46. Liu, T.; Sun, L.; Nordberg, Å.; Schnürer, A. Substrate-Induced Response in Biogas Process Performance and Microbial Community Relates Back to Inoculum Source. Microorganisms 2018, 6, 80. https://doi.org/10.1088/0264-9381/8/10/008.

47. Calusinska, M.; Goux, X.; Fossépré, M.; Muller, E.E.L.; Wilmes, P.; Delfosse, P. A Year of Monitoring 20 Mesophilic Full-Scale Bioreactors Reveals the Existence of Stable but Different Core Microbiomes in Bio-Waste and Wastewater Anaerobic Digestion Systems. Biotechnol. Biofuels 2018, 11, 1-19. https://doi.org/10.1186/s13068-018-1195-8.

48. Hagen, H.L.; Vivekanand, V.; Linjordet, R.; Pope, P.B.; Eijsink, V.G.H.; Horn, S.J. Microbial Community Structure and Dynamics during Co-Digestion of Whey Permeate and Cow Manure in Continuous Stirred Tank Reactor Systems. Bioresour. Technol. 2014, 171, 350-359. https://doi.org/10.1016/j.biortech.2014.08.095. 